University of Chicago Law School

Chicago Unbound

Journal Articles

Faculty Scholarship

2012

\title{
Constitutional Ratemaking and the Affordable Care Act: A New Source of Vulnerability
}

Richard A. Epstein

Paula M. Stannard

Follow this and additional works at: https://chicagounbound.uchicago.edu/journal_articles

Part of the Law Commons

\section{Recommended Citation}

Richard A. Epstein \& Paula M. Stannard, "Constitutional Ratemaking and the Affordable Care Act: A New Source of Vulnerability," 38 American Journal of Law and Medicine 243 (2012).

This Article is brought to you for free and open access by the Faculty Scholarship at Chicago Unbound. It has been accepted for inclusion in Journal Articles by an authorized administrator of Chicago Unbound. For more information, please contact unbound@law.uchicago.edu. 


\title{
Constitutional Ratemaking and the Affordable Care Act: A New Source of Vulnerability
}

\author{
Richard A. Epstein ${ }^{\dagger} \&$ Paula M. Stannard ${ }^{\dagger \dagger}$
}

\section{INTRODUCTION: A MANY-FRONT WAR}

As this Article is being written, the Patient Protection and Affordable Care Act (ACA) is being besieged with two different types of challenges. The first is a Commerce Clause challenge to the individual mandate on the ground that, although the Commerce Clause allows the government to "regulate" the transactions into which people choose to enter, it does not allow the state to force people to enter into disadvantageous transactions against their own will. The second of these challenges deals with the imposition of the Medicaid expansion provisions requiring a state to forego all of its additional Medicaid support unless it is prepared to extend Medicaid coverage, partially at its own expense, to individuals whose income levels put them at $100 \%$ to $133 \%$ of the federal poverty level. The charge is that this requirement represents, through the use of inappropriate conditions, an impermissible compromise of state sovereignty by forcing states to make the choice of taking on the costs of new programs or losing their federal support for their present program.

In this Article, we suggest that the ACA should, and may well, be subject to a third constitutional challenge dealing with a portion of the statute that thus far has escaped systematic judicial scrutiny, but which is likely to loom far larger in importance if both parts of the ACA weather their constitutional assaults - or if the individual mandate is struck down, but the remainder of the ACA survives. We refer to the elaborate set of provisions that regulate health insurance providers in the private market, including their access to the health insurance exchanges, which lie at the core of the private market's operation under the new statute.

The reason that these provisions have thus far escaped judicial notice does not, we believe, have to do with the weakness of the underlying claims. Rather, we think that the real reason is that the conventional wisdom views these provisions-chiefly those dealing with the combination of guaranteed issue and renewal, pre-existing

\footnotetext{
† Laurence A. Tisch Professor of Law, New York University School of Law; the Peter and Kirsten Bedford Senior Fellow, The Hoover Institution; the James Parker Hall Distinguished Service Professor Emeritus and Senior Lecturer, The University of Chicago.

${ }^{\dagger}$ Counsel, Alston \& Bird, LLP; former Deputy General Counsel and Acting General Counsel of the U.S. Department of Health and Human Services. The views expressed herein do not necessarily reflect the views of Alston \& Bird LLP or any of its clients.
} 
conditions, community rating, rate review, and the medical loss ratio ${ }^{1}$ as not amenable to a facial challenge. A facial challenge, in this view, only works if the statute produces an unconstitutional outcome, in all states of the world, for the parties in question. ${ }^{2}$

The normal approach is that such certainty is not attainable in the world of regulatory affairs. We dissent. In some ratemaking schemes, we think that it is possible to identify a system of restrictions so pervasive that this exacting condition is satisfied. Indeed one of us (Epstein) was for a time involved in the litigation over the Durbin Amendment, in which this attack failed. ${ }^{3}$ Nonetheless, we think that a reframed argument can meet the objections lodged against it by showing how the inefficiencies of that scheme of rate caps necessarily reduces consumer welfare in all states of the world. ${ }^{4}$ In connection with the Durbin Amendment, the deadly combination came in two parts. First, a sharp cut in competitive rates that could be collected from retailers. Second, the nominal right to collect money from retail customers that under no circumstances could offset the losses from retailers and which in fact did not yield any new revenues at all.

The theory behind this approach is that the ratemaking cases under the United States Supreme Court tradition do not give the government the same degree of discretion in regulating a particular industry that has sunk costs as they do in allowing general price controls over the economy. The point is made very clear by contrasting two cases, both of which were decided in early 1944. United States v. Yakus ${ }^{5}$ upheld a broad delegation of authority to the federal government to impose price controls on the overall economy based on historical costs, subject only to a very low level of judicial scrutiny, which has proved to be all but useless in practice. ${ }^{6}$ Just months before, the same Supreme Court, speaking through Justice Douglas, upheld a standard that required federal and state regulators to make sure that the rate of return on an equity owner's invested capital was "sufficient to assure confidence in the financial integrity of the enterprise, so as to maintain its credit and to attract capital." ${ }^{\text {,7 }}$ As Hope Natural Gas makes clear, the judicial examination of rate regulation does not turn on the steps that the government takes along the way in reaching its final ruling. Instead, it turns on the need for its bottom line to produce an "end result" that satisfies the substantive standard. ${ }^{8}$ In effect, Hope Natural Gas takes the view that complex ratemaking determinations involve many contested

\footnotetext{
${ }^{1}$ The medical loss ratio (MLR) refers to the level of payout in claims and quality improvement activities relative to premiums collected. An increase in the MLR leaves less room for administrative expenses. A decrease in the MLR leaves more room for administrative expenses.

${ }^{2}$ See, e.g., Williamson Cnty. Reg'l Planning Comm'n v. Hamilton Bank of Johnson City, 473 U.S. 172, 190-91 (1985) (tying the reluctance to hear challenges prior to final decision to the use of constitutional balancing tests for regulatory takings); Hodel v. Va. Surface Mining \& Reclamation Ass'n, 452 U.S. 264, 295 (1981) ("Because appellees' taking claim arose in the context of a facial challenge, it presented no concrete controversy concerning either application of the Act to particular surface mining operations or its effect on specific parcels of land.").

${ }^{3}$ TCF Nat'l Bank v. Bernanke (TCF I), No. CIV 10-4149, 2011 U.S. Dist. LEXIS 45059, at *14 (D.S.D. Apr. 25, 2011), aff'd 643 F.3d 1158 (8th Cir. 2011).

${ }^{4}$ Richard A. Epstein, The Constitutional Paradox of the Durbin Amendment: How Monopolies Are Offered Constitutional Protection Denied to Competitive Firms, 63 FLA. L. REV. 1307 (2011); Richard A. Epstein, Durbin's Folly: The Erratic Course of Debit Card Markets, 7 COMPETITION POL'Y INT'L 58 (2011) [hereinafter, Epstein, Durbin's Folly]. The arguments are developed in sufficient fullness that we shall not try to reproduce them here.

${ }^{5}$ Yakus v. United States, 321 U.S. 414, 422-23 (1944).

${ }^{6}$ Fed. Power Comm'n v. Hope Natural Gas Co., 320 U.S. 591 (1944).

${ }^{7} \mathrm{Id}$. at 603 .

${ }^{8} I d$. at 601-02.
} 
findings, some of which can cut in favor of the regulated utility and some of which can cut against it. The "end result" standard in question forgives the individual errors in dealing with rate calculation on the ground that they will "cancel out" along the way. That determination, however, does not undermine the categorical nature of the final standard, such that, for example, any explicit effort to short-circuit that standard will result in constitutional invalidation. On this score, the key standard is rate of return, not the ability to avoid bankruptcy, which would give far more running room to state regulators. ${ }^{9}$ In Hope Natural Gas, the rate determination came in the context of a challenge to an individual rate, set in a specific hearing. That is the standard that will surely apply to any challenge brought against the various provisions that regulate the health insurance market here.

In many cases, it is said that the high level of deference in ratemaking cases necessarily dooms this inquiry. We take a different view. There are, in fact, a number of important rate cases dealing with, for example, insurance and telecommunications, in which the government's aggressive imposition of rate controls attracted successful constitutional challenge once the courts rightly understood the detailed operation of the particular industry. ${ }^{10}$ In our view, the multiple constraints that the ACA places on the operation of its voluntary exchanges - and on the operation of health insurance companies inside and outside of the exchanges - will sooner or later force the imposition of controls on rates and revenues that will, in combination, yield a confiscatory rate-if they have not done so already. In order to set the stage, Part II of this Article examines in some detail the key features of these provisions that lead to this judgment. Thereafter, Part III shall develop the constitutional arguments in greater detail.

\section{AN ANALYSIS OF THE ACA'S INSURANCE MARKET PROVISIONS}

The ACA is a transformative statute that legislates in bold strokes. Taken together, the ACA's private insurance market provisions ${ }^{11}$-applicable to group plans and to health insurance issuers offering coverage in the individual and group markets-impose significant new coverage mandates that will increase the cost of providing health insurance coverage. At the same time, the ACA's private insurance market provisions will limit or prohibit the traditional insurance practices that enable insurers in other markets to price policies based on risk (either individual or group risk), and constrain premiums and rate increases. In addition, these provisions have two other features that increase their complexity and confusion. The first is that the government has extensive discretion in fleshing out by regulation the key provisions of Title I of the ACA. That situation is further compounded because the discretion extends not only to the articulation of the rules, but also to the granting of short-term

\footnotetext{
${ }^{9}$ Jersey Cent. Power \& Light Co. v. Fed. Energy Regulatory Comm'n, 810 F.2d 1168, 1179 (D.C. Cir. 1987) ("Hope Natural Gas talks not of an interest in avoiding bankruptcy, but an interest in maintaining access to capital markets, the ability to pay dividends, and general financial integrity."); CalFarm Ins. v. Deukmejian, 771 P.2d 1247, 1253 n.9 (Cal. 1989) ("II]f 'insolvency' is defined as 'bankruptcy,' it is clear that rate relief cannot be confined to companies threatened with insolvency.").

${ }^{10}$ See, e.g., Guar. Nat'1 Ins. Co. v. Gates, 916 F.2d 508 (9th Cir. 1990) (striking down insurance rates for insufficiency in guaranteeing a rate of return); Mich. Bell Tel. Co. v. Engler, 257 F.3d 587 (6th Cir. 2001) (setting aside a rate that did not allow the telephone company to obtain a positive rate of return)

${ }^{11}$ Located in Title I of the ACA, these provisions have varying effective dates, including upon enactment, or for plan/policy years beginning on or after September 23, 2010, January 1, 2012, or January 1, 2014. See generally Patient Protection and Affordable Care Act, Pub. L. No. 111-148, Part I, 124 Stat. 119, 130-271 (2010) (codified primarily in scattered sections of 42 U.S.C.A.).
} 
waivers from the application of the rules that is in widespread use today, but subject to little or no published standards. ${ }^{12}$ Second, the basic provisions envision a completed dance between the federal and state governments whereby both have an important say on how the rates are determined. Under this system, the initial examination of the factual record is made by the states (if the states have "effective rate review programs"), with federal oversight and required reporting to the Department of Health \& Human Services (HHS) which issues the rate determination, or by HHS if the states do not have effective rate review programs. ${ }^{13}$ The program necessarily requires close coordination between state and federal governments. The process is supposed to take place on an annual basis, but it seems unlikely that the review cycles can proceed on the rapid timetable needed to make all this work possible. The postponement of deadlines (which happened with the single debit interchange rate regulation published by the Federal Reserve Board ${ }^{14}$ ) is likely to become an integral part of the overall process.

The complexity of the regulatory framework is matched by the magnitude of the ACA's departure from the time-tested principles of insurance law. These principles start from two assumptions, both of which are violated by the ACA. The first assumption defends the principle of freedom of contract on matters of rates and coverage. The second holds that the greatest danger to an effective insurance market is the non-disclosure of key elements, going to the existence or magnitude of the risk, by the insured, not the insurer, who knows far less about the insured's risk, such as the condition of a vessel for which an application of marine insurance was pending. In line with these principles, traditional insurance law gave the insurer the ability to determine whether to accept or reject a designated risk, and to determine the premiums to be charged to an insured, the policy limits, and the terms and conditions on which to issue the policy. In sharp contrast to the ACA, extensive duties to disclose were imposed on the applicants or insureds because they alone possessed the relevant knowledge about the nature and scope of the risk that they were asking the insurer to assume. An applicant/insured was required to make full disclosure of health, health status, and health risks. The insurer would analyze the information and determine whether to accept or reject a given risk (i.e., to cover a given risk), along with risk-based premiums for coverage, the policy limits, and the terms and conditions upon which it issued the policy. The principles that started with individual policies carried over to group insurance, which presented special complications of its own, given the heterogeneity of its members. To the extent that these risks were evenly distributed over the insured population, they tended to cancel each other out. When that happened, the focus of the analysis shifted to the group as a whole, and so, for the most part, the personal characteristics of the beneficiaries were not considered individually.

${ }^{12}$ On the rule of law implications of this practice, see Richard A. Epstein, Government by Waiver, 7 NAT'L AFF. 39 (2011), available at http://www.nationalaffairs.com/publications/ detail/government-by-waiver.

${ }^{13} 45$ C.F.R. $\S 154.210$ (2011).

${ }^{14}$ The Federal Reserve's Final Regulations took effect on October 1, 2011. See Press Release, Bd. of Governors of the Fed. Reserve Sys. (June 29, 2011), available at http://www.federalreserve.gov/newsevents/press/bcreg/20110629a.htm. The regulations were supposed to go into effect on July 21, 2011, the first year anniversary of the Dodd-Frank Wall Street Reform and Consumer Protection Act (Dodd-Frank Act), Pub. L. No. 111-203, § 1075(9), 124 Stat. 1376 (2010) (amending Electronic Fund Tranfer Act § 920(a)(9), 15 U.S.C. § 1693 (2010)) (“(9) EFFECTIVE DATE.-This subsection shall take effect at the end of the 12-month period beginning on the date of the enactment of the Consumer Financial Protection Act of 2010.”). That date was July $21,2010$. 
In this traditional environment, regulation of insurance companies was directed to two different issues. The first aspect of insurance regulation was a general form of consumer protection, which required full disclosure of the terms and conditions of policies or plans, and reviews to ensure that the insurers carried out the terms of their contracts with customers. The insurer's own duty to disclose rates and terms did not negate the insured parties' equally critical duty to disclose information about material risks. The second aspect of insurance regulation addressed insurer solvency, imposing certain financial requirements on insurers, to ensure that the insurer receiving premiums to provide coverage would retain sufficient reserves to enable it to pay the valid policy claims. Competitive forces generally determined premiums. Most state and federal regulation directed insurers to file their policies in order to give fair notice of the rates in question to both state officials and the public at large. In some instances, as with assigned risk pools in automobile insurance, the states imposed rate regulation, creating severe dislocations in the underlying markets, owing to the elaborate cross-subsidies involved.

As we move to a specific discussion of the health insurance market provisions, it is important to note how such provisions apply with respect to plans and policies offered on the exchanges, as opposed to outside the exchanges, and how such provisions apply to pre-existing (or grandfathered) forms of coverage. The provisions discussed below specifically apply to plans and policies offered for sale in the private market. In general, they usually apply to plans and policies offered for sale on the exchanges in the same way. There are several notable exceptions: any large group plans that are offered on the exchanges, as permitted by state decision beginning in 2017, have to offer the essential health benefits package. ${ }^{15}$ They must also provide their plans with actuarial values meeting the "metallic" levels. Any large group plans offered in the private market, however, do not have to meet these requirements. ${ }^{16}$

Under the ACA, only a subset of the health insurance market provisions apply to plans and policies that existed as of the adoption of the ACA ("grandfathered plans"). Accordingly, the ACA permits family members and new employees to be added to such plans or policies without the loss of grandfathered status. ${ }^{17}$ In contrast, the provision requiring coverage of dependents up to twenty-six years of age applies to grandfathered plans, except that, for plan years before 2014, it only applies to group plans if the child is not eligible to enroll in eligible employer-sponsored coverage. ${ }^{18}$ The prohibitions on pre-existing condition exclusions and excessive waiting periods apply only to those grandfathered plans that are group plans. ${ }^{19}$ The provision barring rescission, except for misrepresentation or fraud, applies to grandfathered plans. ${ }^{20}$ The bar on lifetime limits on essential health benefits applies to all grandfathered plans, while the bar on annual limits applies only to grandfathered plans that are group plans. ${ }^{21}$ The medical loss ratio (MLR) provision applies to all grandfathered plans, as does the requirement for the development and distribution of the summary of benefits and coverage. ${ }^{22}$ The implementing regulations adopted by HHS, the Department of Labor, and the Treasury Department

\footnotetext{
${ }^{15}$ Patient Protection and Affordable Care Act $\S 1332(a)(1),(b)(1)(A)$.

${ }^{16}$ See infra at Part A.1.

${ }^{17}$ See Patient Protection and Affordable Care Act $\S 1251(\mathrm{~b})$-(c).

${ }^{18}$ Id. § 1251(a)(4)(A)(iv), (B)(ii).

${ }^{19}$ Id. $\S 1251$ (a)(4)(B)(i)-(ii).

${ }^{20} I d$. $\S 1251(\mathrm{a})(4)(\mathrm{A})(\mathrm{iii})$

${ }^{21} I d . \S 1251(\mathrm{a})(4)(\mathrm{A})(\mathrm{ii}),(\mathrm{B})(\mathrm{i})$.

${ }^{22}$ Id. $\S 1251$ (a)(3).
} 
(1) permit states to impose stricter requirements on grandfathered plans; and (2) apply separately to each benefit package available under a grandfathered health plan.

The status of grandfathered plans is not secure under the ACA. The following changes would cause a grandfathered plan to lose its grandfathered status under the regulations: (1) changes in the scope of benefits; (2) increases in percentage costsharing requirements; (3) increases in fixed-amount cost-sharing (other than copayments), except if limited to medical inflation plus fifteen percentage points; (4) increases in co-payments, except if limited to the above, or five dollars plus medical inflation; (5) decreases in the employer contribution rate of more than five percent below the March 2010 rate; (6) addition of an annual limit on the dollar value of benefits for a plan that did not impose overall annual or lifetime limits as of March 23,2010 ; (7) addition of an annual limit for a plan that imposed only a lifetime limit, unless the annual limit is not less than the lifetime limit; or (8) any lowering of annual limits for plans that had an annual limit as of March $23,2010 .^{23}$ It is commonly understood that the rate of change in technology, economic conditions, and consumer preferences often drove routine modifications in basic plan structure. It is unclear whether the loss of grandfathered status will slow down that process.

\section{A. ACA Coverage Mandates}

\section{Essential Health Benefits}

Traditionally, the benefits covered by an individual health insurance policy or group plan were the subject of negotiation, with benefit packages tailored to the needs of the individuals or groups being covered by the policy or plan, taking into account the features of the group as a whole. The general proposition stated above, that it is proper to ignore individual variations within a group, does not entail that differences between different employee populations should be ignored. Employers do not group themselves randomly, but often sort themselves out by age, sex, occupation, or education. The differences between these groups often called for different types of coverage or different rates for the same type of coverage. For example, a workforce of professionals may have only a tiny fraction of the physical injuries of an industrial workgroup.

Much of that flexibility is lost under the ACA. With the ACA, nongrandfathered plans in the individual and small group markets, whether offered on a health benefit exchange or not, are required to cover "the essential health benefits package." ${ }^{24}$ As drafted, the same basic structure of benefits applies to all plans regardless of the difference in their internal composition. Given the detailed nature of the requirements, the regulatory impact is likely to differ across plans. The point is made evident by looking at some of the key provisions. For starters, section 1302(b) requires that HHS determine, on a periodic basis, the "essential health benefits" to be included in the mandated coverage benefits package. These essential

\footnotetext{
${ }^{23}$ See 45 C.F.R. § 147.140 (2011).

${ }^{24}$ Public Health Service Act $\S 2707$ (a), 42 U.S.C.A. $\$ 300$ gg-6 (West 2012), amended by Patient Protection and Affordable Care Act $\S 1201$ (an "essential health benefits package" is defined by HHS under ACA section 1302(a)). Although large group plans and issuers are not required to provide the essential health benefits, to the extent that such plans provide them, they cannot impose lifetime or annual limits on such benefits. See infra Part A.III. Furthermore, to the extent that, after 2016, states elect to permit sellers of large group plans on their exchanges, such large group plans offered on the exchanges (but not those offered outside of the exchanges) have to offer the essential health benefits package.
} 
health benefits must, by statute, include items and services within ten benefit categories: ambulatory patient services; emergency services; hospitalization; maternity and newborn care; mental health and substance abuse disorder services; prescription drugs; rehabilitative and habilitative services and devices; laboratory services; preventive and wellness services and chronic disease management; and pediatric services. ${ }^{25}$ Each of these bristles with interpretive difficulties. The statute also dictates that HHS ensure that the essential health benefits reflect "an appropriate balance" among these types of services, do not discriminate against individuals because of age, disability, or life expectancy, and cover the full "health needs of diverse segments of the population, including women, children, persons with disabilities, and other groups." ${ }^{26}$ Only plans that offer the essential health benefits package (and meet other requirements) can be designated as "qualified health plans," be offered on the exchanges, and be purchased by individuals who are eligible for financial assistance under the ACA. ${ }^{27}$

The scope of essential health benefits is required to equal the scope of benefits provided under a typical employer plan. ${ }^{28}$ HHS has not yet promulgated a regulatory definition of that term (nor indeed of virtually any of the key concepts set out above), but has issued a bulletin indicating its intent to propose that the essential health benefits package be defined by a state-selected benchmark plan. That benchmark plan, in turn, "would serve as a reference plan, reflecting both the scope of services and any limits offered by a 'typical employer plan' in that State." ${ }^{29}$ For 2014 and 2015, states can select a benchmark plan from among four benchmark plan types identified by Centers for Medicare and Medicaid Services (CMS) ${ }^{30}$ If a state does not make an election, the default state benchmark plan would be the largest plan by enrollment in the largest product in the state's small group market. ${ }^{31}$ If one of the ten benefit categories is not covered by the selected benchmark plan, the state would be required to supplement the plan, again with uncertain financial and coverage implications.

The ACA also dictates that four categories of plans be offered through the exchanges and in the individual and small group market, all of which would have to provide the essential health benefits. The only difference in the plan categories is the percentage of the actuarial value of the benefits covered by the plan, with the bronze category covering sixty percent of the benefits' cost, the silver category covering seventy percent of the benefits' cost, the gold category covering eighty percent of the benefits' cost, and the platinum category covering ninety percent of the benefits' cost. ${ }^{32}$

\footnotetext{
${ }^{25}$ Patient Protection and Affordable Care Act $\S 1302(b)(1)$.

${ }^{26}$ Id. $\S 1302(\mathrm{~b})(4)$.

${ }^{27}$ Id. $\S 1301(\mathrm{a})(1)(\mathrm{B})$.

${ }^{28}$ Id. $\S 1302(\mathrm{~b})(2)$.

${ }^{29}$ Ctr. for Consumer Info. \& Ins. Oversight, Ctrs. for Medicare \& Medicaid Servs., ESSENTIAL HEALTH BENEFITS BULLETIN 8 (2011), available at http://cciio.cms.gov/resources/ files/Files2/12162011/essential_health_benefits_bulletin.pdf.

${ }^{30}$ Id. at 9.

${ }^{31} I d$. HHS intends to assess the benchmark process for 2016 and beyond based on evaluation and
} feedback.

32 Patient Protection and Affordable Care Act $\S 1302(\mathrm{~d})$. The ACA permits issuers to offer a catastrophic plan only in the individual market to individuals who are less than thirty years of age, or those exempt from the requirements to maintain "minimum essential coverage" pursuant to provisions relating to individuals without affordable coverage options or with hardship exemptions. Id. $\S 1302(\mathrm{e})$ 


\section{Cost-Sharing}

The ACA limits the ability of plans and issuers to require cost-sharing. The total cost-sharing (including deductibles, co-insurance, co-payments, etc.) for all categories is the same; it is set for 2014 at the total out-of-pocket expenses permitted for health savings accounts high deductible plans and may be adjusted for health insurance inflation. ${ }^{33}$ The size of the deductible is limited to $\$ 2000$ for an individual and $\$ 4000$ for a family in the small group market, amounts that may be subject to adjustment. ${ }^{34}$ For persons between $100 \%$ and $400 \%$ of the federal poverty level, the ACA further reduces the out-of-pocket limits insurers are permitted to require. ${ }^{35}$

\section{Lifetime and Annual Limits}

Public Health Service (PHS) Act section 2711 bars group health plans and health insurance issuers in the group or individual market from imposing lifetime or annual limits on the dollar value of the essential health benefits. Prior to 2014, "restricted annual limits" may be imposed for essential health benefits. ${ }^{36}$ Plans and issuers can impose lifetime and annual limits on benefits that are not essential health benefits. ${ }^{37}$ As noted above, the bar on lifetime limits on essential health benefits applies to all grandfathered plans, while the bar on annual limits applies only to grandfathered plans that are group plans.

\section{Specific Benefit Mandates}

In addition, the ACA also dictates that certain specific benefits must be offered.

\section{a. Preventive Services}

Under PHS Act section 2713, group health plans and health insurance issuers offering group or individual health insurance coverage are required to provide coverage for preventive health services-without cost-sharing. ${ }^{38}$

\footnotetext{
${ }^{33} I d . \S 1302(\mathrm{c})(1),(4) ;$ I.R.C. $\S 223(\mathrm{c})(2)(\mathrm{A})(\mathrm{ii})$ (West 2012).

${ }^{34}$ Patient Protection and Affordable Care Act $§ 1302(\mathrm{c})(2),(4)$.

${ }^{35} \mathrm{Id} . \S 1402$.

${ }^{36}$ Public Health Service Act $\S 2711$ (a)(2), 42 U.S.C.A. 300gg-11 (West 2012), amended by Patient Protection and Affordable Care Act $§ 1001$. This limit is $\$ 750,000, \$ 1.25$ million, and \$2 million, respectively, for plan years starting between September 23, 2010, and September 22, 2011; September 23, 2011, and September 22, 2012; and September 23, 2012, and January 1, 2014. 45 C.F.R. $\S 147.126(d)$ (2010). HHS provided a process for limited benefit, or mini-med, plans to obtain a waiver of these limits, to permit such coverages to continue to have lower annual limits for essential health benefits, $i d$. $\S 147.126(\mathrm{~d})(3)$, but has ceased accepting applications for such waivers. The provision applies to grandfathered plans and coverages, except that annual limits do not apply to grandfathered individual health insurance coverages.

37 Public Health Service Act $\S 2711 ; 45$ C.F.R. $\S 147.126(b)(1)$. Prior to the issuance of regulations defining essential health benefits, the enforcing agencies will accept good faith efforts to comply with a reasonable interpretation of the term, as long as the plan or issuer applies the definition consistently. See Patient Protection and Affordable Care Act: Preexisting Condition Exclusions, Lifetime and Annual Limits, Rescissions, and Patient Protections, 75 Fed. Reg. 37188, 37191 (June $28,2010)$.

${ }^{38}$ See Public Health Service Act $\S 2713$. The ACA identifies the categories of services considered to be "preventive." See id. § 2713(a). Plans are not required to cover out-of-network preventive services and may impose cost-sharing requirements with respect to such services. 45 C.F.R. $\S 147.130(a)(3)$.
} 


\section{b. Dependent Coverage}

Under new PHS Act section 2714, if a group health plan or a health insurance issuer offering group or individual coverage provides dependent coverage, the plan must make such coverage available for adult children up to age twenty-six. ${ }^{39}$ As noted above, this provision applies to grandfathered plans, except that, for plan years before 2014, it only applies to group plans if the child is not eligible to enroll in eligible employer-sponsored coverage.

\section{c. Choice of Healthcare Professionals and Referral Requirements}

If the designation of a primary care physician is a feature of a group plan or individual policy, the plan or insurer must permit the designation of any participating primary care physician (including a pediatrician, for children) available to accept the individual. ${ }^{40}$ If coverage is provided for obstetrical or gynecological care, the plan or issuer cannot require authorization or referral of a female enrollee seeking such care from in-network specialists. ${ }^{41}$ Covered hospital emergency department services must be permitted without prior authorization and coverage limitations, regardless of the hospital's status under the plan or policy; cost-sharing for out-of-network emergency department services is required to be the same as for in-network hospitals. ${ }^{42}$

\section{d. Approved Clinical Trials}

The ACA bars health plans and insurers offering group or individual market coverage from (1) prohibiting qualified individuals ${ }^{43}$ from participating in approved clinical trials $;^{44}$ (2) denying, limiting, or placing conditions on the coverage of routine patient costs (items or services consistent with plan coverage for qualified individuals not enrolled in a clinical trial) associated with participation in such a clinical trial; and (3) discriminating against qualified individuals on the basis of their participation in approved clinical trials. ${ }^{45}$

The ACA "coverage mandates"- coupled with the limitation on cost-sharing (and the bar on cost-sharing for "preventive services") by beneficiaries and plan participants - will likely spur utilization (and over-utilization) of covered services by beneficiaries. This will inevitably increase the cost to plans and issuers of providing coverage.

${ }^{39}$ Public Health Service Act $\S 2714$. This requirement applies to grandfathered plans; prior to 2014 , such plans are not required to make dependent coverage available for adult children who can enroll in their employer's health plan.

${ }^{40} I d . \S 2719$ A(a), (c); 45 C.F.R. $\S 147.138(a)(1)-(2)$.

${ }^{41}$ Public Health Service Act $\S 2719$ A(d); 45 C.F.R. $\S 147.138(a)(3)$. Regulations promulgated under the PHS Act section 2719A require that applicable plans provide notice of these rights to each participant. 45 C.F.R. § 147.138(a)(4).

${ }^{42}$ Public Health Service Act $\S 2719$ A(b); 45 C.F.R. § 147.138(b).

${ }^{43}$ Public Health Service Act $§ 2709$ (b).

${ }^{44} I d$. $\S 2709$ (d) (generally limited to clinical trials relating to the prevention, detection or treatment of cancer or other life-threatening diseases or conditions, and approval or funding by certain federal agencies or a study/investigation conducted under an Investigational New Drug (IND) application reviewed by the Food and Drug Administration or exempted from an IND application).

${ }^{45}$ Id. 


\section{B. ACA Changes to Traditional Insurance Practices}

At the same time that the ACA's coverage mandates are likely to increase the cost of coverage, other ACA provisions limit the ability of plans and health insurance issuers to engage in traditional insurance practices that would enable them to control or limit the risk they accept, especially in the small group and individual markets.

\section{Exclusions or Limitations of Coverage for Pre-Existing Conditions}

The ACA bars exclusion of coverage for pre-existing conditions. ${ }^{46}$ Group health plans and issuers offering group or individual coverage cannot impose any preexisting condition exclusions ${ }^{47}$ with respect to such plans or coverage. ${ }^{48}$ The ACA bars exclusion of coverage for certain benefits, as well as complete exclusion from the plan or coverage, if the exclusion is based on a pre-existing condition. ${ }^{49}$ This provision applies to grandfathered plans that are group plans. ${ }^{50}$

\section{Waiting Periods}

The ACA bars any group health plan and any group health insurer from imposing any waiting period greater than ninety days. ${ }^{51}$ This prohibition applies to grandfathered plans that are group plans. ${ }^{52}$

\section{Health Status, Eligibility for Insurance, and Premiums}

The ACA also bars health plans from basing eligibility or premiums on certain health status factors. Group health plans and group or individual health insurers cannot establish rules for eligibility (or continued eligibility) based on certain healthrelated factors of an individual or a dependent of an individual. These factors include health status, medical condition, claims experience, receipt of healthcare, medical history, genetic information, evidence of insurability, disability, or any other HHS-

${ }^{46} I d . \S 2704(\mathrm{a})$.

${ }^{47}$ Defined as "a limitation or exclusion of benefits relating to a condition based on the fact that the condition was present before the date of enrollment for such coverage, whether or not any medical advice, diagnosis, care, or treatment was recommended or received before such date." Id. $\S 2704(\mathrm{~b})(1)(\mathrm{A})$.

${ }^{48}$ Id. $\$ 2704$. The provision applies to enrollees under the age of nineteen for plan or policy years beginning on or after September 23, 2010, and to all others for plan or policy years beginning on or after January 1, 2014. Id. $\S 1255$. The prohibition on pre-existing condition exclusion also applies to grandfathered plans that are group health plans. Patient Protection and Affordable Care Act, Pub. L. No. 111-148, § 1251 (2010) (codified as amended at 42 U.S.C.A. $\S 18011$ (West 2012)).

${ }^{49}$ Prior to the ACA, under the Health Insurance Portability and Accountability Act of 1996 (HIPAA), Pub. L. No. 104-191, pre-existing condition exclusion rules applied only to group health plans and group health insurance coverage, and permitted exclusions of coverage based on preexisting conditions under certain circumstances. Compare Public Health Service Act § 2701(b)(1), 42 U.S.C. $\S 300 \mathrm{gg}$ (2006), amended by Patient Protection and Affordable Care Act $\S 1201$, with Public Health Service Act $\$ 2704(\mathrm{~b})-(\mathrm{g}), 42$ U.S.C.A. § $300 \mathrm{gg}-3$ (West 2012). Where an individual had eighteen months of "creditable coverage" and had previously been covered by one of several types of plans, individual market insurers were barred from imposing a pre-existing condition exclusion, unless the state provided an alternative mechanism by which to cover such individual. Patient Protection and Affordable Care Act $\S 2741$ (a)(1)(B), (b).

${ }^{50}$ Patient Protection and Affordable Care Act $§ 1251(\mathrm{a})(4)(\mathrm{b})(\mathrm{i})$.

${ }^{51}$ Public Health Service Act $\S 2708$. A "waiting period" is "the period that must pass with respect to the individual before the individual is eligible to be covered for benefits under the terms of the plan." Id. § 2704(b)(4).

${ }_{52} I d . \S 1251(\mathrm{a})(4)(\mathrm{a})(\mathrm{i})$. 
designated health-status-related factor. ${ }^{53}$ Similarly, such entities may not require any individual, based on any health-status-related factor, to pay a premium or contribution greater than such premium or contribution for a similarly situated individual. ${ }^{54}$ Group health plans may, however, continue to offer premium discounts or rewards based on enrollee participation in wellness programs. ${ }^{55}$

\section{Guaranteed Issuance and Renewability ${ }^{56}$}

The ACA requires, subject to certain limitations, that each health insurance issuer offering health insurance coverage in the individual or group market in a state must accept every employer and individual in the state that applies for such coverage. ${ }^{57}$ An insurer may restrict enrollment to open and special enrollment periods; limit, subject to certain restrictions, enrollment in networked plans based on the service area and capacity of the networked plan; and deny coverage if the issuer does not have the financial reserves necessary to underwrite additional coverage. ${ }^{58}$ Upon denying coverage based on network or financial capacity, however, the issuer may not offer coverage in the group or individual market for a period of 180 days (or, with respect to financial capacity, until the issuer has demonstrated to the applicable state authority, if required, that it has sufficient financial reserves to underwrite additional coverage) ${ }^{59}$ The ACA also adopts and reiterates the preexisting provisions requiring guaranteed renewability of coverage at the option of the sponsor or policyholder.

\section{Prohibition on Rescissions}

PHS Act section 2712 allows rescission of coverage-cancellation or discontinuance of the coverage with retroactive effect—by a group health plan or a

${ }^{53} I d . \S 2705(\mathrm{a})$.

${ }^{54}$ Id. $\S 2705(\mathrm{~b})(1)$. Prior to the ACA, HIPAA and the Genetic Information Nondiscrimination Act of 2008 barred group health plans and issuers from establishing eligibility rules for individuals, or requiring individuals to pay premiums or contributions greater than such premiums or contributions paid by other individuals in the plan, based on certain health-status-related factors (including genetic information). Public Health Service Act $\$ 2702,42$ U.S.C. $\$ 300 \mathrm{gg}-1$ (2006), amended by Patient Protection and Affordable Care Act $\S 1201(3)(A)$. However, with the exception of genetic information, PHS Act section 2753, such limitations did not apply in the individual health insurance market. Public Health Service Act $\$ 2753$

${ }^{55}$ Public Health Service Act $\$ 2705(\mathrm{~b})(2)(B),(j)$.

56 "Guaranteed issuance" is the requirement that the health insurance issuer accept every applicant for health coverage, as long as the applicant agrees to the terms and conditions of the insurance offer (premiums, out-of-pocket costs, and coverage limitations). "Guaranteed renewability" is the requirement on a plan or health insurance issuer to renew group or individual coverage at the option of the plan sponsor or policyholder, respectively.

${ }^{57} \mathrm{Id}$. $\S 2702$ (a). The provision is based on a similar pre-ACA provision that was applicable only to the small group market. See Public Health Service Act § 2711, 42 U.S.C. § 300gg-11, amended by Patient Protection and Affordable Care Act $\S 1001(3)$. In limited circumstances, where individuals had eighteen months of creditable coverage, individual market insurers were required to guarantee issue policies. See Public Health Service Act § 2741(a)(1)(B), (b).

${ }^{58}$ Public Health Service Act $\S 2702$ (b)-(d). In the latter two circumstances, the issuer may be required to demonstrate to the applicable state authority that it is applying the restriction uniformly to all employers and individuals, without regard to the claims experience of the individuals, employers and employees, and their dependents, or to any health-status-related factor. $I d$.

${ }^{59} I d . \S 2702(\mathrm{c})(2),(\mathrm{d})(2)$.

${ }^{60}$ See id. $\$ 2703$ (requiring renewal or continuation of coverage except for non-payment of premium, fraud, violation of participation or contribution rates, termination of coverage, movement outside the service area, cession of association membership, and providing for uniform modification of coverage), amended by Patient Protection and Affordable Care Act § 1201; see also id. § 2742. 
group or individual health insurance issuer only for a covered individual "who has performed an act or practice that constitutes fraud or makes an intentional misrepresentation of material fact as prohibited by the terms of the plan or coverage." ${ }^{\circ 1}$ Prior to the ACA, this heightened standard for rescission did not exist under most state insurance law, which also allowed rescission in cases of material nondisclosure. Under the ACA, moreover, cancellation requires prior notice to the enrollee. ${ }^{62}$ Implementing regulations require that the entity provide "at least 30 days advance written notice to each participant (in the individual market, primary subscriber) who would be affected before coverage may be rescinded ... regardless of, in the case of group coverage, whether the coverage is insured or self-insured, or whether the rescission applies to an entire group or only to an individual within the group. ${ }^{63}$ This provision applies to grandfathered plans. ${ }^{64}$

\section{Community Rating}

The ACA prohibits health insurance issuers in the individual or small group market from varying premium rates, except with respect to: age (where the permitted maximum variation is $3: 1$ ); state premium rating areas; family composition (individual or family); and tobacco use (where the maximum permitted variation is $1.5: 1){ }^{65}$ These limits also apply to all large group plans and insurers (whether offered on the exchange or outside of the exchange) if a state permits health insurance issuers offering such coverage to offer it through the exchange. ${ }^{66}$

\section{The Adverse Selection Risk}

Taken together, these provisions require the covered plans and insurers to cover any group or individual that applies (and pays the premiums), prevent insurers from charging different premiums based on different risks (except in very limited circumstances), and require them to cover such groups' or individuals' health expenses, regardless of any health conditions that predated the coverage. The provisions create significant risk of adverse selection by permitting individuals, with the payment of a penalty that is relatively insignificant compared to the cost of the health insurance coverage, to engage in strategic behavior by consciously foregoing the purchase of health insurance until they become ill or otherwise decide that they want to obtain certain healthcare services. Once that crisis is past, they may drop the health insurance with impunity in order, once again, to take advantage of the low penalty for dropping coverage. Opening up this opportunity for some will, in turn, necessarily increase the cost of health insurance for those who purchase it over the long run, especially since insurance companies are required to meet the ACA's coverage mandates, and cannot adjust the level of services provided in order to decrease the cost of the coverage. The higher rates have the real risk of increasing the fraction of individuals who join and withdraw strategically from these plans. Done over several iterations, the additional rounds of adverse selection could lead to a potential death spiral for insurance companies.

\footnotetext{
${ }^{61} I d . \S 2712$.

${ }^{62} I d$.

${ }^{63} 45$ C.F.R. $\S 147.128(a)(1)(2010)$.

${ }^{64}$ Id. $\S 147.128(\mathrm{c})$.

${ }^{65}$ Public Health Service Act $§ 2701(\mathrm{a})(1)$.

${ }^{66} I d$. $\S 2701(\mathrm{a})(5)$. Large group employers would be permitted to access the health insurance exchanges under ACA section 1312(f)(2)(B).
} 
The ACA also creates several programs for transfer payments among health insurance issuers. States are required to establish a transitional reinsurance program "to help stabilize premiums for coverage in the individual market in a State during the first 3 years of operation of an Exchange ... when the risk of adverse selection related to new rating rules and market changes is greatest." ${ }^{967}$ In the program, assessments are collected from all insurers and third-party administrators on behalf of group plans for the period 2014-2016; the amounts collected under the program are earmarked for reinsurance payments to health insurance issuers that cover high risk individuals (as that term is defined in the ACA) in the individual market. ${ }^{68}$

The ACA also contains a transitional risk corridor program that HHS is to run for 2014-2016 in order to equalize burdens across plans. ${ }^{69}$ Under this program, HHS will collect amounts from qualified health plans in the small and individual market (including exchanges) if their allowable costs (total costs other than administrative costs) are less than a certain percentage of the target amount (total premium reduced by the administrative costs) and will pay amounts (according to a preset formula) to such health plans if the plan's allowable costs exceed the target amount. ${ }^{70}$

Finally, each state is to establish a permanent risk adjustment program. Pursuant to the program, the state is to assess a charge on health plans and health insurance issuers in the individual or small group market (both in and outside the exchange) if the actuarial risk of its enrollees is less than the average actuarial risk of all enrollees in all plans or coverage in the state. ${ }^{71}$ In line with the overall objective of equalizing risk across plans, it will provide payments to plans if the actuarial risk of the plans' enrollees for the year is greater than the average actuarial risk of all enrollees in all plans or forms of coverage in the state for the year. ${ }^{72}$ The ACA directs HHS to establish criteria and methods to be used in the program. ${ }^{73}$

These authorized transfer payments from some health insurers to other health insurers are ostensibly based on the relative risks or costs of the individuals they cover. The programs, however, are subject to two serious objections.

The first is that the forces of adverse selection may prove so powerful that all insurers find themselves subject to coverage obligations that exceed their revenues. That outcome could happen if future patients gravitate in large numbers to the insurers whose healthcare insurance profile best fits their needs, resulting in overall increases in utilization. If this situation results, all programs would be eligible to receive transfers, but none could be obliged to provide it, which is clearly an unsustainable position.

The second objection, which applies whenever one insurer sustains heavier losses than others, is that the transfer obligations can at most postpone the problem facing insurance companies, without directly addressing the adverse selection risk. It follows that the ACA's efforts to equalize risk will not prevent the downward insurance spiral described above. Nothing in these provisions addresses the risk of adverse selection or strategic behavior on the part of individuals who can decide to purchase health insurance only when they want or need healthcare services. The statutory design of the ACA thus fails to confront directly the likely spiral of

${ }^{67}$ Patient Protection and Affordable Care Act, Pub. L. No. 111-148, § 1341 (2010), 124 Stat. $119,208-11$ (codified as amended at 42 U.S.C.A $\S 18061$ (West 2012)).

${ }^{68} \mathrm{Id}$.

${ }^{69} I d . \S 1342(\mathrm{a})$.

${ }^{70}$ Id. § 1342 .

${ }^{71}$ Id. § 1343(a)(1).

${ }^{72} I d . \S 1343(\mathrm{a})(2)$

${ }^{73}$ Id. $\S 1343$ (b). 
increasing costs driving increasing premiums and driving more individuals to join and withdraw strategically from the plans.

Beyond these substantive requirements, the ACA contains several provisions that impose significant procedural, reporting, and/or disclosure requirements on group health plans and health insurers in the group and individual markets, including the provisions which require (1) group health plans and insurers in the group and individual markets to have an effective internal claims appeal process and external review process $;{ }^{74}(2)$ the establishment of an Internet portal by which the public can access information about all available insurance products, for which health insurers are required to submit detailed information to HHS on each of their small group and individual market products and "portal plans;", plans and sponsors of self-insured group plans, to create a summary of benefits and coverage explanation, containing information on the coverage provided by each plan or policy (including grandfathered plans) and to provide it to applicants, enrollees, and policy or certificate holders; ${ }^{76}$ (4) group plans and insurers offering group or individual coverage to make available certain information about itself and its practices $;{ }^{77}$ and (5) group plans and insurers offering group or individual coverage to provide annual reports to HHS and to their enrollees on activities undertaken to improve quality of care, health outcomes, and wellness and health promotion. ${ }^{78}$

\section{ACA Provisions Restricting Premiums and Rate InCREASES}

There are several provisions that explicitly or implicitly restrict the amount of premiums or revenue that a health insurance company can earn under the ACA.

\section{Review of "Unreasonable" Rate Increases}

The ACA requires HHS and the states to establish a process for reviewing increases in health plan premiums, and requires plans to justify increases. ${ }^{79}$ It requires the states to report on trends in premium increases and recommend whether certain plans should be excluded from the exchanges because of unjustified premium increases. ${ }^{80}$ Plans may well have to accept smaller premium increases than would be economically appropriate to avoid being excluded from the exchanges. Specifically, PHS Act section 2794, ${ }^{81}$ applicable to the small group and individual health insurance markets, requires HHS, in conjunction with the states, to establish a process for the annual review of "unreasonable increases in premiums for health insurance coverage." ${ }^{\prime 82}$ Health insurance issuers must submit to HHS and the relevant state a justification for unreasonable premium increases prior to the implementation of the increase ${ }^{83}$ HHS is required to ensure public disclosure of information on such

${ }^{74}$ Public Health Service Act $\S 2719$ (a), 42 U.S.C. $\S 300 \mathrm{gg}-1$ (2006), amended by Patient Protection and Affordable Care Act $\S 10101$ (g), 42 U.S.C.A. § 300 gg-19 (West 2012).

${ }^{75}$ Patient Protection and Affordable Care Act $\S 1103(a)$; 45 C.F.R. $\S 159.100$ (2010).

${ }^{76}$ Public Health Service Act $§ 2715$.

${ }^{77} I d . \S 2715 \mathrm{~A}$

${ }^{78} I d . \S 2717$.

${ }^{79} I d . \S 2794(\mathrm{a})$

${ }^{80} \mathrm{Id} . \S 2794(\mathrm{~b})$.

${ }^{81} I d . \S 2794$

${ }^{82} I d . \S 2794(\mathrm{a})(1)$.

${ }^{83}$ Id. § 2794(a)(2) 
increases and the justifications therefore, and such issuers are required to post prominently such information on their websites. ${ }^{84}$

Implementing regulations require insurers seeking rate increases of ten percent or more, for non-grandfathered plans in the small group and individual markets, to submit a preliminary justification to HHS and/or the relevant state on such proposed increases prior to implementation of the increase.$^{85}$ This review process involves the submission of extensive data ${ }^{86}$ HHS will publicly disclose such information on its website, consistent with its Freedom of Information Act regulations. ${ }^{87}$ The rates will be reviewed by the state (if it has an "effective rate review program"); ${ }^{88}$ otherwise, HHS will conduct the review. ${ }^{89}$ In that case, HHS will determine that an increase is an "unreasonable rate increase" if it is an "excessive rate increase," rate increase," determination on its website. If an insurer decides to proceed with an increase despite a CMS or state determination of its "unreasonableness," it must submit to CMS a final justification, and post on its website (for at least three years) the information on the increase posted on the Internet by CMS, the CMS or state final determination, and its final justification. ${ }^{93}$

While HHS does not have authority to reject rate increases, HHS has, nevertheless, called upon certain health insurance issuers to rescind putatively unreasonable proposed premium increases. For example, HHS Secretary Kathleen Sebelius recently stated with respect to rate increases proposed by one insurer: "It's

${ }^{84} \mathrm{Id}$.

${ }^{85} 45$ C.F.R. $\S \S 154.200(\mathrm{a}), 154.215(\mathrm{a})-(\mathrm{g})(2011)$.

${ }^{86}$ Id. As of September 1, 2012, the ten percent threshold may be replaced by a state-specific threshold determined by HHS. Id. $\S 154.200(\mathrm{a})(2)$. The preliminary justification must include information and data on a number of issues, including a rate increase summary and a written description justifying the rate increase. Id. $\S 154.215(\mathrm{e})$. The written description has to include a narrative describing the data and assumptions used to develop the rate increase, an "[e]xplanation of the most significant factors causing the rate increase, including a brief description of the relevant claims and non-claims expense increases reported in the rate increase summary," and a "[b]rief description of the overall experience of the policy, including historical and projected expenses, and loss ratios." Id. § $154.215(\mathrm{f})$

${ }^{87}$ Id. $\S 154.215(\mathrm{i})$

${ }^{88}$ Id. $\S 154.210$ (a)-(b). The regulations set forth the factors that HHS will consider with respect to each insurance market in the state in determining whether a state has an effective rate review program. Id. $\S 154.301$ (a).

${ }^{89}$ As of February 16, 2012, HHS will conduct some or all of the review in seven states and two territories as to the increases proposed for the small group and individual market, and in twenty-two states with respect to increases proposed for association products. Health Insurance Rate Reviews: Lowering Costs for American Consumers and Businesses, List of Effective Review Programs, CTR. FOR CONsumer Info. \& Ins. Oversight, Ctrs. FOR MedicAre \& MedicAid SERvs., http://cciio.cms.gov/resources/factsheets/rate_review_fact_sheet.html (updated Feb. 16, 2012).

90 A rate increase is excessive if it "causes the premium charged for the health insurance coverage to be unreasonably high in relation to the benefits provided under the coverage," based on (1) whether it results in an MLR below the Federal MLR standard in the relevant market; (2) whether any assumptions are not supported by substantial evidence; and (3) whether the choice or combination of assumptions on which the rate increase is based is unreasonable. 45 C.F.R. $\S 154.205$ (b)

91 An increase is unjustified if the issuer provides data or documentation that is "incomplete, inadequate or otherwise does not provide a basis upon which the reasonableness of an increase may be determined." Id. $\S 154.205$ (c).

${ }^{92}$ An increase is unfairly discriminatory if it "results in premium differences between insureds within similar risk categories that: (1) Are not permissible under applicable State law; or (2) In the absence of an applicable State law, do not reasonably correspond to differences in expected costs." Id. $\S 154.205(\mathrm{~d})$.

${ }^{93}$ Id. $\S 154.230(\mathrm{c})$. 
time for [the insurance company] to immediately rescind the rates, issue refunds to consumers or publicly explain their refusal to do so." ${ }^{, 4}$

In addition, as a condition of receiving "premium review grants," state insurance commissioners are required to make appropriate recommendations "to the State Exchange about whether particular health insurance issuers should be excluded from participation in the Exchange based on a pattern or practice of excessive or unjustified premium increases. ${ }^{, 5}$ HHS, in conjunction with the states, is directed to "monitor premium increases of health insurance offered through an Exchange and outside of an Exchange." $" 96$ The statute also permits the states, in deciding whether to include large group qualified health plans in the exchanges, to consider "any excess of premium growth outside the Exchange as compared to the rate of growth inside the Exchange." 97 These provisions may well enable HHS, and/or the states, to influence the rates charged in the large group market, even when no large group coverage is offered through an exchange.

In addition, the separate authority of the states (with the potential encouragement of HHS) to exclude from the exchanges any small group or individual plan that has excessive or unjustified premium increases may prove to give the states a de facto power to set maximum rates, which brings the entire ACA closer to a traditional ratemaking situation applied to public utilities. The source of this power lies in the ability of the states to exclude recalcitrant insurers from the exchanges' health insurance markets, which are the only markets in which tax credits are available to assist individuals with purchasing health insurance. Being unable to access this potentially new and ever-expanding market may well place the excluded insurers at a decisive competitive disadvantage in comparison to those insurers that operate in the exchange. Which way the ultimate balance runs, however, is presently quite unclear because there is no guarantee that the subsidy will be sufficient to offset the stiff requirements imposed on all exchange carriers. The situation is even more perilous, however, because the decision not to participate in these exchanges does not relieve the firm from obligations under the ACA, including (for small group plans and issuers offering individual and small group coverage) offering the essential healthcare packages, which deny them any flexibility in the kinds of coverage they may offer.

There is a critical efficiency loss attributable to this regimentation of healthcare plans. In the open market, competition takes place not only with respect to price, but also with respect to other features of these complex business arrangements between insurer and insured. Some of these differences are embodied in contractual provisions with their customers that alter the bundle of goods in order to maximize the gains from trade in the market. Still other differences come from the choice of specialized services to be offered, or in the locations where they are offered. The relentless standardization under the ACA stifles the competition in all of these relevant dimensions. In so doing, it causes a loss of much of the business know-how that, in unregulated markets, count as important firm assets, which are often protected as trade secrets. These losses make the position of all firms more perilous

\footnotetext{
${ }^{94}$ News Release, Affordable Care Act Holding Insurers Accountable for Premium Hikes, Health \& Human Servs. (Jan. 12, 2012), available at http://www.hhs.gov/news/press/2012pres/ 01/20120112a.html.

95 Public Health Service Act $\S 2794($ b)(1), 42 U.S.C.A. § 300gg-94 (West 2012). Such commissioners are also required to provide information to HHS on trends in premium increases.

${ }^{96}$ Id. § 2794(b)(2)(A).

${ }^{97}$ Id. § 2794(b)(2)(B)
} 
than before. They also increase the odds that the ACA's novel web of provisions could force insurers to acquiesce to the lower rates demanded by HHS or the states - if it does not drive them out of business, either nationally or in particular states.

\section{Medical Loss Ratio}

Subject to the qualifications set out above, the ACA does not contain any explicit rate regulations. Nonetheless, it does contain provisions that influence the rates that health insurers can charge and the rebates that they must offer. In its most notable provision, the ACA requires that health insurance issuers in the small group or individual markets spend at least eighty percent of premium revenue, and that health insurance issuers in the large group market spend at least eighty-five percent of premium revenue ${ }^{98}$ on medical claims or clinical services, and healthcare quality activities. If they do not, they are required to refund the difference to enrollees on an annual basis. Grandfathered plans and plans and policies that are not offered over the exchanges are subject to this provision. ${ }^{99}$

Health insurance companies (including those offering grandfathered plans) are required to submit an annual report to HHS on the ratio of incurred losses (or claims) and loss adjustment expense to earned premium (the "medical loss ratio"). ${ }^{100}$ These reports are required to include the percentage of premium dollars (after accounting for risk adjustment, risk corridor, and reinsurance payments or receipts) spent on "clinical services," activities to improve healthcare quality, and all other non-claim costs (not including federal or state taxes and licensing or regulatory fees, and after certain fees are excluded) beginning with the 2010 plan year. ${ }^{101}$ Implementing regulations require the reporting of the amount of premium revenue received for the MLR reporting year, ${ }^{102}$ and the amounts expended on (1) reimbursements for clinical services provided to enrollees; ${ }^{103}$ (2) activities that improve healthcare quality for enrollees; ${ }^{104}$ (3) all other "non-claims" costs; ${ }^{105}$ and

\footnotetext{
${ }^{98} I d . \S 2718$
}

${ }^{99}$ Small and large group determinations are based on the number of employees-regardless of whether they are full-time or part-time-employed by the employer sponsor. The ACA increased the small group limit from fifty to 100 employees, see id. $\S 2794$, but until 2016, states can elect to use fifty employees as the size limit for small group plans for purposes of the MLR. 45 C.F.R. $§ 158.103$ (2010) (defining large employer).

${ }_{100}$ Public Health Service Act $\$ 2718(a)$.

${ }^{101} I d$. $\S 2718(\mathrm{a})$.

10245 C.F.R. $\$ 158.130$.

${ }^{103}$ This includes direct claims paid to providers, including under capitation arrangements, unpaid claim reserves associated with claims incurred during the MLR reporting year, the change in contract reserves, reserves for contingent benefits and the claim portion of lawsuits, and any experience rating refunds paid or received. Id. § 158.140(a) (defining "incurred claims").

${ }^{104}$ Under the regulations, an activity only constitutes a quality improvement activity if it falls into one of the categories in PHS Act section 2717 and meets four other requirements set forth in the regulation. Id. $\S 158.150(\mathrm{~b})$. The regulations specifically identify certain activities that cannot be reported as quality improvement activities. See id. $\S 158.150(\mathrm{c})$. Only certain health information technology expenditures can be considered quality improvement activities. Id. § 158.151.

${ }^{105}$ This includes expenses for administrative services, including cost-containment expenses that are not included as a quality improvement expenditure, loss adjustment expenses, salaries and benefits, agents' and brokers' fees and commissions, general and administrative expenses (including expenditures for regulatory compliance), and community benefit expenditures. $I d$. § 158.160(b)(2). 
(4) federal and state taxes and licensing and regulatory fees. ${ }^{106}$ Each issuer (i.e., legal entity) must separately report this information (even if under common ownership with other issuers) on a state-by-state basis for each of the large group, small group, and individual markets. ${ }^{107}$

Beginning in 2011, if the percentage of revenue spent on clinical services and healthcare quality activities does not meet or exceed eighty-five percent of the total premium revenue (excluding federal and state taxes and licensing or regulatory fees, and after accounting for risk adjustment, risk corridor, and reinsurance payments or receipts) in the large group market or eighty percent of the total premium revenue in the individual or small group market, the insurer is required to pay a rebate to each enrollee under such coverage on a pro rata basis in the amount of the difference. ${ }^{108}$ The ACA authorizes individual states to increase the amounts that must be spent on claims and quality improvement activities by increasing the MLR (and, thus, decrease the amount of revenue available for administrative and other expenses). ${ }^{109}$ HHS can adjust (i.e., reduce) the MLR and the rebate requirement in the individual market if it finds that such rebates will destabilize the market in a state. ${ }^{110}$ In addition, HHS can adjust (reduce) certain MLR rates (and, thus, increase the amounts insurers can spend on administrative costs) if it deems it appropriate on account of the volatility of the individual market due to the establishment of the exchanges. ${ }^{111}$

States cannot unilaterally reduce the ACA-required MLRs for the benefit of the health insurance companies. Under the ACA and the MLR regulations, a state, but not the health insurance company, may file an application for such adjustments in or reductions of the MLR in order to allow its own insurers to increase administrative costs without facing a rebate obligation. ${ }^{12}$ As of February 16, 2012, HHS has received a total of eighteen requests from states or territories for temporary reductions to the statutory MLR, to reduce the MLR and, accordingly, decrease the amount of premium revenue required to be spent on claims and quality improvement activities, and, thereby, increase the amounts that can be spent on administrative and other expenses. ${ }^{113}$ HHS has resolved these requests by completely denying eleven requests and apparently granting (but only in part) the other seven. ${ }^{114}$

${ }^{106} I d$. $\S \S 158.161-.162$. These provisions permit the exclusion of federal and state taxes and certain licensing and regulatory fees, but not of federal income taxes on investment income and capital gains. Id. $\S 158.161(\mathrm{a})$.

${ }^{107} \mathrm{Id}$. $\S 158.120$.

${ }^{108}$ Public Health Service Act $\S 2718(\mathrm{~b})(1)(A)$, amended by Patient Protection and Affordable Care Act $\S 10101(\mathrm{f}), 124$ Stat. 119, 885-91, 42 U.S.C.A. § 300gg-18 (West 2012). Starting in 2014, calculation of the MLR is to be based on the average of the premiums expensed on the costs and the total premium revenue for each of the previous three years for the plan. Id.; see also 45 C.F.R. $\S 158.221$.

${ }^{109}$ See id. $\S 158.211$. In making such adjustments in the rebate requirement, the state is directed to "seek to ensure adequate participation by health insurance insurers, competition in the health insurance market in the State and value for consumers so that premiums are used for clinical services and quality improvements." Public Health Service Act § 2718(b)(2).

${ }^{110}$ See 45 C.F.R. $\$ 158.301$.

${ }^{111}$ Public Health Service Act $\S 2718(d)$.

11245 C.F.R. $\S 158.301$

${ }^{113}$ See Medical Loss Ratio, CTR. FOR CONSUMER Info. \& Ins. Oversight, CTRS. FOR MEdiCARE \& MEDICAID SERVS., http://cciio.cms.gov/programs/marketreforms/mlr/index.html (last visited Apr. 3, 2012).

${ }^{114} \mathrm{Id}$. 
Implementing regulations provide direction to issuers on how to calculate the MLR, ${ }^{115}$ and provide for adjustment to the MLR based on the credibility of the issuer's experience. ${ }^{116}$ To the extent that the MLR is less than required, a rebate is payable to each enrollee or to the group policyholder, subject to an exception for de minimis rebates. ${ }^{117}$ Issuers are also required to report payments of MLR rebates to HHS, and to provide notice of any MLR rebates to current group health plan subscribers, group policyholders, and subscribers in the individual market. The notices must contain certain specified information, including how rebates may be used in the group market. ${ }^{118}$ HHS may defer an issuer's obligation to pay MLR rebates only if such payments would cause its risk-based capital level to fall below specific regulatory thresholds (relating to solvency), and the relevant state regulatory official so informs HHS. ${ }^{119}$ If HHS determines that this would occur, it may defer payment of all or a portion of the rebates, but only for the period of time determined by HHS in consultation with the state. At such time when the payment would not cause the issuer's risk-based capital to fall below the regulatory solvency thresholds, the issuer would be required to pay the rebates plus interest. ${ }^{120}$

Because the MLR provision caps non-claim and non-quality improvement activities at twenty percent for the small group and individual market and fifteen percent in the large group market ${ }^{121}$ — which is generally lower than pre-ACA stateimposed MLRs (and defined differently) - it effectively caps administrative expenses (including regulatory compliance costs) and profits at those below-market percentages. This occurs when statutory compliance costs are sure to rise because of multiple compliance requirements that are chocked in the statute. As we shall now demonstrate, it is easy to envision scenarios in which the MLR provision may preclude insurance companies from earning any return on their investment. It is even possible to envision scenarios in which insurance companies may be required to pay rebates while operating at a loss. Indeed, it is clear that in many cases the application of the statute could drive otherwise stable companies into bankruptcy if they are caught by the one-two punch of higher costs and lower revenues. The only temporary relief from the obligation to pay any required MLR rebates occurs if the company's solvency is threatened by the payment of the rebates.

\section{THE ECONOMIC AND CONSTITUTIONAL ANALYSIS}

We are now in a position to examine the constitutionality of the ACA in light of its many interlocking health insurance market provisions. The initial point of concern is the fundamental theory of regulation that drives this statute. We take it as a given that no health insurance carrier, no matter how large, shares any of the

11545 C.F.R. $\S 158.221$.

${ }^{116} I d$. $\S \S 158.230-.232$. Any MLR based on experience from fewer than 1000 life-years is not credible and no rebates are owed for non-credible experience/plans. Credibility adjustments are permitted for MLRs based on experience of 1000 to 75,000 life-years, deemed "partially credible." Id.

${ }^{117} I d$. $\S \S 158.240,158.242-.244$. Under the exception, which insurers may choose to employ, all de minimis rebates must be aggregated by market and distributed in equal amounts to all enrollees entitled to a rebate. Rebates can be paid to the group policyholder in the case of group health plans that are not subject to Employee Retirement Income Security Act and are not non-federal governmental plans only if the issuer receives written assurance that the rebates will be used to benefit enrollees. $I d$.

${ }^{118} I d . \S \S 158.260,158.250$

${ }^{119}$ Id. $\$ 158.270$ (a).

${ }^{120}$ Id. $§ 158.270(\mathrm{~d})$.

${ }^{121}$ See supra note 105 and citation therein. 
inherent characteristics of the standard regulated public utilities, such as gas and electricity. Those public utilities all operate in particular territories where they are shielded from competition either by explicit legal protections or by the high cost of entry. They also supply a single homogeneous good—gas or electricity — that is easy to deliver and measure, and thus to regulate. It is an established theorem in these markets that a single firm that is left unconstrained by the threat of new entry can price their services in ways that yield monopoly rates of return extracted from consumers who have nowhere else to go. Accordingly, the hallmark of this form of public utility regulation is a "take all customers position" that requires that all rates be set on a "reasonable and nondiscriminatory basis" for the benefit of customers. ${ }^{122}$ The utility's quid pro quo is a rate of return that is consistent with the risk-adjusted rate of return on the investments of competitive industries.

At this stage, we do not want to accept uncritically the desirability of all public utility regulation, for its ultimate soundness depends on a wide range of features that deal with a number of factors. ${ }^{123}$ Some short-term regulation can, for example, deter entry by new players whose technological improvements could turn an existing monopolistic industry into a competitive one. Conversely, some regulatory regimes can be so oppressive as to starve the regulated firms of the capital needed for longterm improvements.

For our purposes, however, the simple point is that when these errors take place in the public utility context, there remains a cushion of potential industry profits that explains why the regulation of such natural monopolies could make sense. There is, as far as we can see, no parallel justification in the health insurance market. There are no territorial or product monopolies. There is cut-throat competition among large and sophisticated suppliers who deal with sophisticated employers who know that if they do not supply decent coverage to their employees, they risk the loss of their services. There are smaller group purchasers that are anxious about healthcare costs, and individuals who also search the market. There are barriers to interstate competition (which have been made worse under the ACA), but these are often avoided by big national companies that compete through local subsidiary corporations. What is missing is any systematic evidence that these markets fail because of excessive concentration of a few firms that might, in principle, justify rate regulation. There are, to be sure, always informational gaps in health insurance markets, but many of these are already subject to a variety of disclosure regulations - and are now subject to additional disclosure requirements under the ACA. The ACA is not after that small game, however. While some ACA provisions may be aimed at requiring additional disclosure to remedy perceived information gaps, most disclosures required by the ACA are provided to government agencies, which use that information to set the terms and conditions for the regulated party, or to monitor whether the insurer is in compliance with ACA requirements. ${ }^{124}$

The simplest challenge to this regulation is that it ignores all of the differences between public utilities and insurance companies. It then compounds the problem by

${ }^{122}$ See Harold Demsetz, Why Regulate Public Utilities?, 11 U. CHI. J.L \& EcON., 55, 55-65 (1968); Richard A. Posner, Natural Monopoly and Its Regulation, 21 STAN. L. REV. 548, 548-643 (1969)

${ }^{123}$ See sources cited supra note 122 for the sustained critiques.

${ }^{124}$ Speaking generally, disclosure requirements work best in free, competitive markets, where the disclosure rectifies informational imbalance. In a highly regulated market, the benefit from information disclosure requirements may be marginal, given that other regulatory requirements may address the result of the informational imbalance (e.g., disclosure of prices/premium increases versus rate regulation). 
treating health insurance firms as though they were monopolistic public utilities, without affording them the protection that the Constitution extends to these firms. ${ }^{125}$ Tick down the features that bit by bit convert health insurance companies from market firms to regulated industries. The ACA requires guaranteed issue and renewability, which means that they must take all customers who fall within a given group, as it is with public utilities. There is a provision on rescissions that parallels the rule that all customers must be served on the system. There is an essential health benefits package that cannot be reduced, which parallels the minimum service provisions applicable to public utilities. There is community rating, which is the imposition of cross-subsidies similar to those found in many regulated industries, including, by way of example, the conscious decision in the telecommunications industry to have rates charged to businesses subsidize homeowner rates. Those subsidies are not possible in a competitive industry. In the ACA, there is a set of complex mechanisms that imposes de facto rate limitations. The MLR is one such device, and the ability of the federal government (or the state insurance regulators) to declare rate increases unreasonable, and thus force companies off the exchanges is a powerful price control mechanism. The usual reference to an exchange is a place where all can come to sell their own products on their own terms. In this context, however, the exchange reduces all freedom on price and quality of goods.

Indeed, there is only one feature of the standard public utility that is not present: protection of constitutional rates of return. Our position is that this cannot be achieved in practice by any scheme that combines, as the ACA does, higher compliance costs and lower rates of return. That outcome is a constant no matter what particular course of action is taken by the federal government and the various states, either acting alone or in concert, in going about their regulatory business. If we start from the assumption that the firms in this industry are now earning only a risk-adjusted competitive rate of return - and no one has suggested otherwise-what justification is there for imposing this huge set of requirements on the entire industry? In this situation, there are some differences of position between those health insurance issuers that are on the exchange and those that are not. But this is decidedly not the case where regulation is imposed only on those firms that have opted voluntarily into the ACA. To opt in voluntarily necessarily implies that one could opt out without penalty. Yet the ACA and the implementing regulations make it very clear that grandfathering is at most a ghostly presence that will likely not last a generation, and that any health insurance providers that leave the ostensible cocoon of the exchanges will not be free of government regulation. We see this as a "damned if you do, damned if you don't" situation. We also see that the interlocking and overlapping set of ACA provisions makes it hard to draw any hard-and-fast line between various different types of plans based on the differential impact of government regulation. What happens in one area will clearly influence the marketing prospects that happen in the next. The regulation of health insurance

\footnotetext{
${ }^{125}$ For early statements of this position, see Richard A. Epstein, Impermissible Ratemaking in Health-Insurance Reform: Why the Reid Bill Is Unconstitutional, MED. Progress TODAY (Dec. 18, 2009), http://www.medicalprogresstoday.com/enewsletters/mpt_ind.php?pid=1834\&nid=250, for which Paula Stannard supplied extensive assistance, and the spin-off column, Richard A. Epstein, Harry Reid Turns Insurance Into a Public Utility, WALL ST. J. (Dec. 22, 2009), http://online.wsj.com/article/SB10001424052748704304504574610040924143158.html?mod=rss opi nion_main ("The health bill creates a massive cash crunch and then bankruptcies for many insurers.").
} 
markets stands or falls as a whole, given the inability to disentangle its component parts.

We do not think that the case for regulation can be made on the ground of improved efficiency. Quite simply, it is hard to see what lingering market inefficiency survives with health insurance firms that are already subject to multiple levels of regulation. Freed from regulation, all these health insurance companies have the conventional incentive to maximize their profits, which in the standard scenario means that they will only engage in certain expenditures to the point where the extra dollar that is paid out brings an extra dollar in. The entire edifice of antitrust law rests on the assumption that this desirable equilibrium is routinely reached in competitive markets. Without explanation, the ACA assumes that these markets fail by that test, without showing wherein that failure lies. To be clear, the justification for the MLRs cannot be that firms do not minimize administrative costs in order to maximize profits. They are doing that right now with their current allocation of services, so that the additional limits on administrative costs mean that certain important services, such as fraud prevention, are necessarily curtailed because of the want of the needed resources to combat them.

A second objection is that the costs have to be lowered in order to increase access to healthcare. True enough, but that could be done without the extensive web of regulations under the ACA. A simple decision to open up insurance markets to interstate competition, or to allow nontraditional firms, such as retailers and drug stores, to compete in the healthcare market, or to eliminate mandates, could all achieve these goals. What cannot be said is that the higher costs justify regulatory requirements such as the MLR, which may impose losses on firms that now are required to take all comers. This spurious high-cost justification has never worked in ordinary public utility regulation, and it should not be allowed to work here, where it would in short order not only deprive firms of a sensible rate of return but could drive them into bankruptcy. It might, in principle, be acceptable to make up the shortfall out of general tax revenues, but that alternative was expressly negated in this case, where the entire history of the ACA shows that its supporters moved heaven and earth to keep it out of the tax system. ${ }^{126}$

At this point, the question is the likelihood that the regulated firms' return on investment meets the appropriate constitutional standard. It cannot if competitive markets are throttled. One desirable feature of markets is that parties enter into agreements only when entities on both sides of the transaction perceive gains from trade. The way in which these gains are created is that the sellers of any given type of product seek to ensure that each attribute of that product is worth more to the consumer than its cost. The endless package of mandates that is imposed through the ACA is not battle-tested in that fashion. Consumers of a given income level, given full information about these various features, could easily decide to do without some higher level of protection in order to free up money to acquire alternative goods and services. Indeed, one of the main reasons for the decline in employer-sponsored insurance coverage has been the proliferation of mandates at the state level, all of which cost more than they are worth to consumers. The Council for Affordable Health Insurance produced a detailed catalogue of some 1961 state mandates as of

${ }^{126}$ See, e.g., Obama: Requiring Health Insurance Is Not a Tax Increase, CNN.com (Sept. 20, 2009) ("For us to say you have to take responsibility to get health insurance is absolutely not a tax increase.”), http://articles.cnn.com/2009-09-20/politics/obama.health.care_1_health-insurancecoverage-mandate-medicare-advantage?_s=PM:POLITICS. 
$2008 .{ }^{127}$ One or two mandates might not sink an insurance policy. But a dozen or two might well not only lead to a reduction in the parties' surplus, but also reverse the ratio of costs to benefits so that the coverage is dropped.

The implicit assumption of the entire ACA is that the "right" to healthcare can be evaluated without any consideration of the correlative duties that are imposed on others. Thus, the argument that it is unfair to charge individuals a higher premium for pre-existing conditions flies in the face of traditional insurance law because it requires the insurer to charge a fee that does not cover the loss in question. ${ }^{128}$ In order for the business to survive, therefore, it must charge other customers-those who have the opportunity to pay the low cost of exit from the plans (i.e., the low penalty) - to pick up the difference. There is little or no reason to think that anything in the ACA calibrates those higher charges to offset the subsidies that are created. The only alternative, therefore, is for the health insurer to provide the coverage at a loss. What is true about pre-existing conditions is true about every one of the detailed provisions that relate to guaranteed issue, automatic renewal, community rating, minimum coverage, and so on. If these provisions made sense, they would be in the policies or plans already. But since they generally are not in all policies, we have to assume that each of them is in some sense an economic loser.

Within the basic framework, therefore, the rate-of-return argument seems clear. In dealing with the same issue in connection with the debit charge interchange fee, one of us (Epstein) gave a few simple mathematical relationships to demonstrate what should be accepted without such argument. In a competitive industry, there is no way in which to lower rates, raise costs, and preserve a risk-adjusted competitive rate of return. ${ }^{129}$

At this point, the argument from confiscation runs as follows. There is no pretense whatsoever that the new regulations in question will apply solely to new firms who have entered the market. The use of such regulations would be unwise insofar as it distorts competitive costs, but it would be constitutional under the Hope Natural Gas test or any of its permutations, because the new arrival would have entered the business with open eyes and, thus, would have to take whatever the legal regime imposed. Yet it is precisely for that reason we can be confident that few firms will choose to enter the health insurance industry now if they know that they have to face the ACA regulations for existing firms. Existing firms, however, do not have effective exit rights because of the huge amount of capital that they have sunk into their businesses, which will have to be sold for salvage value if they quit the business. Their business goodwill would be gone in liquidation; their existing leases and service contracts would have to be cancelled, often with payments to suppliers;

127 For discussion, see Victoria Craig Bunce \& JP Wieske, Council For AfFordable Health Ins., HeAlth InSURANCE MANDATES IN THE StATES 2008, at 2 (2008), available at http://heartland.org/sites/all/modules/custom/heartland_migration/files/pdfs/23616.pdf. For updates, see Victoria CRaig Bunce \& JP Wieske, Council For AfFordable Health Ins., HeAlth INSURANCE MANDATES IN THE STATES 2010 (2010), available at http://cdm15029.contentdm.oclc.org/ $\mathrm{cdm} /$ singleitem/collection/p266901coll4/id/3763/rec/1http://www.cahi.org/cahi_contents/resources/pd f/MandatesintheStates2010.pdf. Its report contained the warning that "more [mandates] are on their way." Id. For the dislocations from mandates, see Richard A. Epstein, Bleak Prospects: How Health Care Reform Has Failed in the United States, 15 TEX. REV. L. \& POL. 1 (2010).

128 Prior limitations on the use of pre-existing condition exclusions were applicable where individuals had a certain amount of "creditable coverage" — that is, they had obtained insurance (even if not with the particular insurer) for a certain period of time. The purpose of this provision is to offer some assurance to insurers that the individuals had paid premiums to an insurer and were not engaging in strategic behavior. See supra at note 49.

${ }^{129}$ For the particulars, see Epstein, Durbin's Folly, supra note 4, at 69. 
and their internal management and operations systems would be worth at most a fraction of their value, if worth anything at all. The ability to sell the entire business could only take place at a huge discount because no sensible buyer would pay a price that guarantees it a real loss. There is no doubt that existing firms would have substantial losses. In dealing with the same issue in connection with the Durbin Amendment, one of us (Epstein) dealt with the Durbin paradox: there is no sensible way to say that firms in competitive markets get no protection when firms that have the cushion of a natural monopoly do get that protection. ${ }^{130}$ The risk of confiscation through low rates, which is present in both cases, is surely greater for the competitive firm that is operating at the margin than it is for the monopolist that has some price cushion from punitive rate regulation. We conclude, therefore, that the only sensible reading of the situation is that the higher compliance costs and lower revenues are, in constitutional terms, a fatal combination.

But what about the general rule that does not allow for these challenges until there is an actual conflict with the law? In our view, there are two answers to that question. The first is that, in ordinary ratemaking hearings, the regulated firm gets to challenge the rates prior to their being put into place. It is widely understood that being forced to operate at a loss cannot be offset by allowing the firm to recoup additional sums from customers later in the process if the rates prove too low. In these cases, the rates are allowed and refunds to customers, administratively a far easier process, can be ordered if the rates prove to be excessive. In principle, the ACA allows a hearing of this sort, but no matter how the responsibility for that review is allocated between state and federal officials, it may not be credible to believe that these reviews can be accomplished in an orderly fashion. That orderly outcome is even less likely given the large number of individual cases that are likely to be subject to administrative review at any one time. Yet the ACA makes no provision at all for what interim rate increases, if any, should be allowed pending completion of the state or federal review. The central principle that rate reductions should be publicly vetted before they are implemented looks to be a casualty of the ACA.

The second answer goes to the question of whether regulated firms can show losses in all events. In one sense, these economic losses need not arise, given the degree of discretion that is lodged in the system. The government could always back off at critical moments. But we already have enough information that regulators are in no mood to compromise. There are an enormous number of firms that are subject to regulation. It seems a virtual certainty that some of them will be cut down by the regulations, given that the inability to control the customer base will lead to some subset of health insurance providers who, by the luck of the draw, will be saddled with far more expensive pools than their competitors, for which ad hoc adjustments after the fact are likely to fall short. It is equally clear that the forms of relief on a case-by-case basis are likely to be late-coming and insufficient in amount. That difficulty is only more acute because the ACA's transitional reinsurance and risk corridor programs, and its risk adjustment program, do not address the underlying problem of adverse selection and the strategic behavior of individual insureds. Those additional losses should be taken into account in setting rates, but there is no obvious mechanism in this program for doing so. It is possible, but not probable, to envision a set of successful health exchanges whose members can thrive while subject to a set of ad hoc rules that do not apply to their competitors. It is possible, but not probable,

\footnotetext{
${ }^{130}$ See id. at 58-70.
} 
to think that all of these health plans can make money when, unlike public utilities, they enjoy no territorial monopoly and face customers armed with a credible option to drop their health insurance coverage in times of slack demand. To insist that each firm should be placed on a different timetable for rate review is to guarantee that no one in any part of the market can plan his affairs in a coherent fashion. The difference in market structure fully justifies pulling back from a rule that promises relief only after the system has collapsed.

We think that comprehensive and forward-looking relief is justified for yet another reason. These restrictions are so draconian that in most cases the fight about individual rates in the face of system-wide uncertainty is little better than rearranging the deck chairs on the Titanic. The supposed subsidies made available under the ACA may bring additional consumers into the healthcare market. But they will do nothing to ease the problems of companies who care more about the number of dollars coming their way than the source of those dollars and find that, as a result of all of the health insurance market provisions, the dollars are insufficient to meet their new obligations. At this point, the only real quarrel is, as with the Durbin Amendment, with the size of the future losses incurred once this scheme is put into place. But since the government under the ACA has absolutely no intention to compensate firms for their regulatory losses, immediate judicial relief is appropriate to prevent massive business losses that will take place under the new ACA provisions. The damage from insufficient rates pervades the warp and woof of the ACA. The regulatory takings argument thus has real weight even if the problems with the individual mandate and the Medicaid program are put to one side.

\section{CONCLUSION}

We are well aware of the conventional wisdom that holds that it is impossible to mount credible rate-of-return challenges to financial regulation in the health insurance industry. Nonetheless, we think that this general view rests on certain basic misapprehensions that this Article is intended to correct. First, there are cases today where the requirement of a "bottom line" rate of return has led courts to block the imposition of confiscatory rates. These precedents fall on fertile ground under the ACA. We have shown that the ACA imposes heavy-handed regulation of key features of the standard insurance policy. These address guaranteed issue and renewability, with the inability to price separately for pre-existing conditions; the ability of customers to go in and out of coverage on a strategic basis; the cross subsidies of community rating; and the heavy clubs over rates found in the ability of the government to pressure firms to decrease or eliminate rate increases, to exclude non-complying firms from the exchanges, and to order rebates when expenditures exceed some preset medical loss ratio that allocates to administrative costs and overhead less than virtually all private plans do in the voluntary market. We do not think that it can be the case that every private firm is deficient in ways that government regulation can fix without serious dislocation. On these issues, the real knowledge base is in the private sector, which is under assault in a multi-front war. Given that these mandates and restrictions were adopted as part of a package of health insurance market reforms, they must be evaluated as part of a package. Once that is done, it is clear that few, if any, new firms will enter this market, and those who are already there are at risk of expropriation of their invested capital-that is, of failing to earn a risk-adjusted rate of return on their investment. In a case where the fates of so many competitive firms are heavily entwined, there is no room for error 
in setting rates or in supplying relief. We conclude, therefore, that the only way to avoid the risk of chaos in the health insurance market is to repeal or strike down this legislation, leaving it to Congress to devise a plan that better addresses the desire to improve access, quality, and cost in healthcare systems. 
Copyright of American Journal of Law \& Medicine is the property of American Society of Law, Medicine \& Ethics and its content may not be copied or emailed to multiple sites or posted to a listserv without the copyright holder's express written permission. However, users may print, download, or email articles for individual use. 